\title{
REPOSITORI INSTITUSI : Hak Cipta dan Peran Pustakawan
}

\author{
P. Iman Hery Wahyudi \\ Universitas Pelita Harapan \\ imanhery@gmail.com
}

\begin{abstract}
Institutional repositories are preservation media for all scientific works published by institutions. The repository is open access, so it can be accessed by all academics and other parties. Librarians have a very strategic role in building and developing institutional repositories. But on the other hand librarians are also obliged to protect the copyright of scientific works contained within it. Librarians must have information literacy competencies. Information literacy skills are one solution to avoid copyright infringement, so the provision of information literacy skills for students is an obligation for every institution.
\end{abstract}

Keywords: copyright, institutional repository, open access, information literacy

\begin{abstract}
Abstrak
Repositori institusi merupakan media preservasi bagi semua karya ilmiah yang diterbitkan oleh institusi. Repositori bersifat open akses, sehingga bisa diakses oleh segenap civitas akademika maupun pihak lain. Pustakawan memiliki peran yang sangat strategis didalam membangun dan mengembangkan repositori
\end{abstract}


institusi. Tetapi disisi lain pustakawan juga wajib menjaga hak cipta dari karya ilmiah yang ada didalamnya. Pustakawan harus memiliki kompetensi literasi informasi. Ketrampilan literasi informasi merupakan salah satu solusi untuk menghindari pelanggaran hak cipta, maka pembekalan ketrampilan literasi informasi bagi mahasiswa menjadi suatu kewajiban bagi setiap institusi.

Kata Kunci: hak cipta, repositori institusi, open akses, literasi informasi

\section{A. Pendahuluan}

Pengembangan repositori institusi di Indonesia sudah mulai digalakan terutama bagi perpustakaan perguruan tinggi. Keberadaan repositori institusi sangat strategis, karena bukan hanya sebagai preservasi karya ilmiah melainkan juga sebagai media komunikasi ilmiah bagi internal civitas akademi maupun ekternal.

Repositori dapat memberikan gambaran tentang (1) karyakarya intelektual, (2) inovasi yang telah dihasilkan dan (3) kualitas institusi tersebut. Karena perkembangan iptek yang dikembangkan oleh civitas akademik dapat diketahui melalui repositori. Dapat diibaratkan repositori sebagai wajah dari perguruan tinggi yang bersangkutan.

Repositori sebaiknya dikelola oleh perpustakaan, karena sejalan dengan salah satu peran perpustakaan perguruan tinggi. Rancangan metadata repositori melibatkan pustakawan sebagai end user sampai maintenance. Tetapi keberhasilan dalam pengembangannya, terletak pada kolaborasi dengan pihak lain, seperti jurusan, fakultas maupun unit-unit lain didalam institusi tersebut. keterlibatan jurusan atau fakultas dalam pengembangan ini didasari atas kesadaran untuk unggah mandiri hasil karya civitas akademik.

Tidak sedikit dari mahasiswa, dosen maupun peneliti yang enggan untuk mengunggah karyanya kedalam repositori. Hal ini disebabkan oleh (1) faktor ketidaktahuan mereka akan adanya 
repositori, (2) kurangnya promosi baik dari pustakawan maupun pihak-pihak yang terkait dan (3) aspek legalitas. Aspek legalitas disini berkaitan dengan perlindungan karya intelektual, yaitu copyright (hak cipta).

Copyright menjadi unsur sensitive bila dihubungan dengan open akses. Segala yang berhubungan dengan open akses selalu bersinggungan dengan hak cipta dari penulis. Dalam repositori memungkinkan semua karya yang dihasilkan dapat diakses oleh siapa saja. Bila suatu karya telah di publikasikan secara online, dan bisa diakses oleh siapapun maka karya tersebut sudah menjadi domain publik.

Pihak institusi maupun penulis tidak bisa membatasi siapa saja yang boleh mengakses, karena hal ini justru berlawanan dengan hakekat open akses tersebut. Setiap orang berhak untuk membaca, mengunduh atau menyebarluaskan kembali sejauh tidak melanggar hak cipta penulis. Namun yang perlu digarisbawahi adalah bagaimana kita bisa melindungi hak moral dari karya intelektual dan upaya apa yang perlu kita lakukan sebagai pustakawan.

\section{Rumusan Masalah}

Repositori institusi merupakan preservasi karya ilmiah yang dihasilkan oleh institusi, dan bersifat open akses. Kemudahan dalam mengakses fulltext dalam repositori memberikan permasalahan tersendiri bagi pustakawan. Satu sisi pustakawan harus memberikan akses sumber informasi seluas mungkin bagi civitas akademik, namun disisi lain pustakawan juga wajib melindungi hak cipta dari semua karya ilmiah.

\section{Tujuan Penelitian}

Penelitian ini bertujuan untuk mengetahui upaya apa saja yang perlu diklakukan oleh pustakawan dalam melindungi hak moral intelektual penulis dari setiap karya ilmiah mereka yang ada di dalam repositori institusi. 


\section{Metode}

Metode yang digunakan dalam penelitian ini adalah

1. Kajian pustaka, dimana penelitian yang datanya diambil terutama atau seluruhnya dari kepustakaan (Irawan, 2000), terutama kepustakaan yang berkaitan dengan repositori dan hak cipta.

2. Wawancara, dimana penelitian yang datanya dikumpulkan atau didiskusikan dengan responden atau nara sumber (Irawan, 2000), dalam hal ini seorang yang kompeten dalam hukum hak cipta.

\section{Tinjauan Pustaka}

\section{Repositori}

Menurut kamus Merriam-Webster, repositori merupakan tempat penyimpanan sesuatu yang bersifat non material, pengertiannya sama seperti buku yang merupakan tempat penyimpanan dari ilmu pengetahuan. Demikian juga menurut macmillandictionary, mengartikan repositori sebagai seseorang, sebuah buku, perpustakaan dan sebagainya sebagai tempat penyimpanan informasi dan pengetahuan.

Bila merujuk dari dua pengertian diatas, maka pada prinsipnya repositori sebagai tempat penyimpanan informasi atau pengetahuan, lebih tepatnya dalam perpustakaan dikenal dengan istilah preservasi. Preservasi disini lebih merujuk pada semua karya intelektual yang dihasilkan oleh institusi tersebut.

Karya intelektual apa saja yang dikeluarkan oleh institusi tersebut, secara garis besar terbagi menjadi 3, yaitu

1. Mahasiswa, yang bisa diupload kedalam repositori termasuk didalamnya skripsi, tesis disertasi, makalah penelitian

2. Fakultas, diantaranya kertas kerja, presentasi, laporanlaporan, pre-print dan post-prints. 
3. Institusi secara lembaga, diantaranya hasil akreditasi institusi maupun program studi, laporan tahunan, SK kebijakan institusi

\section{Peran repositori}

Menurut Gibbons (2004) manfaat repositori institusi, yaitu tata kelola, efisiensi, penyebarluasan karya, dan krisis komunikasi ilmiah. Sedangkan Gani (2015), menjelaskan keuntungan yang didapat oleh institusi dalam menerapkan repositori sebagai berikut (1) melestarikan karya intelektual sivitas akademik, (2) berbagi pengetahuan, (3) pengembangan riset dan pengabdian masyarakat, (4) tata kelola informasi yang baik dan (5) citra tri darma perguruan tinggi.

Sedangkan menurut Pandapotan dalam Wiyarsih (2015), peran repositori institusi ada 4 yaitu (1) untuk mengumpulkan konten dalam satu lokasi sehingga mudah untuk ditemukan kembali, (2) untuk menyimpan dan melestarikan aset intelektual sepanjang waktu, (3) untuk menyediakan akses terbuka terhadap karya intelektual institusi kepada khalayak umum dan (4) untuk menciptakan visibilitas global bagi karya ilmiah institusi.

Yeates dalam Ratanya (2017) mengatakan bahwa peran repositori institusi adalah sebagai berikut

extending the range of knowledge sharing, existing investment in information and content management systems can be leveraged; and more flexible ways of scholarly communication are available.

Suber (2007) menambahkan repositori institusi juga dapat meningkatkan visibilitas, retrievabilitas dan dampak dari hasil penelitian yang dihasilkannya.

\section{Hak cipta}

Hak cipta menurut Undang-undang Republik Indonesia nomor 19 tahun 2002, adalah hak eksklusif bagi pencipta atau penerima hak untuk mengumumkan atau memperbanyak 
ciptaannya atau memberikan izin untuk itu dengan tidak mengurangi pembatasan-pembatasan menurut peraturan perundang-undangan yang berlaku.

Dalam lingkup civitas akademika hak cipta dari karya ilmiah sangat diperhatikan dan dilindungi. Karya ilmiah menurut Peraturan Mendiknas no.17 tahun 2010, bab 1 pasal 1 menyebutkan karya ilmiah adalah hasil karya akademik mahasiswa/dosen/ peneliti/tenaga kepandidikan di lingkungan perguruan tinggi, yang dibuat dalam bentuk karya tulis baik cetak maupun elektronik yang diterbitkan dan/atau di presentasikan.

\section{Open akses}

Pengaruh dari perkembangan teknologi informasi dan komunikasi, yaitu ketersediaan sumber-sumber informasi yang terpasang sehingga memudahkan pengguna untuk akses informasi tanpa terbatas waktu dan tempat atau dikenal dengan istilah open access. Menurut the Budapest Open Access Initiative (BOAI) (2002), pengertian open access sebagai berikut:

its free availability on the public internet, permitting any users to read, download, copy, distribute, print, search, or link to the full texts of these articles, crawl them for indexing, pass them as data to software, or use them for any other lawful purpose, without financial, legal, or technical barriers other than those inseparable from gaining access to the internet itself. The only constraint on reproduction and distribution and the only role for copyright in this domain should be to give authors control over the integrity of their work and the right to be properly acknowledged and cited.

\section{Manfaat open akses}

BOAI (2012) merekomendasikan agar semua jurnal artikel dibuat open akses, karena melalui open akses artikel dapat dipublikasikan relatif lebih awal daripada bentuk tercetak, yang publikasinya jauh dari tanggal penyerahan jurnal itu sendiri. 
Dengan kata lain open access lebih current dibandingan dengan printed journal.

Melalui open akses, artikel ilmiah yang dibuat civitas akademisi lebih terlihat (visible), dapat ditemukan kembali (retrievable) dan bermanfaat bagi peneliti (useful) sebagai sarana sumber ilmiah terpasang (Chigbu, Njoku dan Uzoagba, 2016), penyebarluasan informasi penelitian secara dijital tanpa biaya (Veena, 2016).

Menurut Covey (2010) dampak open akses yang positif bagi (1) bagi peneliti, karena dengan adanya open akses akan memberikan ketepatan waktu dan dampak karya mereka, akses gratis ke karya peneliti lain, kolaborasi dan inovasi karya., (2) bagi pustakawan, merupakan solusi minimnya dana untuk jurnal berbayar dan mengatasi izin untuk menggunakan jurnal ilmiah., dan (3) bagi negara berkembang, mereka dapat mengakses penelitian yang tidak terjangkau dan membagikan karya penelitian dari peneliti negara maju.

\section{B. Pembahasan}

\section{Open akses dan Hak cipta}

Open akses memberikan kemudahan bagi siapa saja untuk memanfaatkan karya ilmiah yang dibuat oleh peneliti lain. Kemudahan tersebut diantaranya dapat mengunduh karya ilmiah secara fulltext dan current. Kemudahan ini tentunya memberikan dampak yang signifikan bagi institusi yang memiliki keterbatasan dana dalam pengadaan jurnal. Bagi beberapa institusi yang memiliki anggaran terbatas tentunya akan berfikir ulang bila harus melanggan jurnal dengan biaya langgan sangat besar (Covey, 2010).

Open akses merupakan salah satu cara berbagi pengetahuan kepada peneliti lain. Secara normatif open akses digunakan sebagai bahan referensi, acuan ataupun tolok ukur terhadap penelitian yang sedang dilakukan. Open akses juga memberikan peluang sesama peneliti untuk melakukan kolaborasi dalam menghadapi 
obyek penelitian yang sama, sehingga mampu menciptakan inovasi baru.

Disatu sisi open akses juga memberikan peluang niat yang tidak etis. Kemudahan tersebut dengan melakukan copy-paste karya ilmiah peneliti lain, baik sebagian maupun secara keseluruhan sebagai miliknya. Mengakuisisi dan mengklaim sebagai karya yang dibuat sendiri, dengan mengesampingkan peneliti aslinya sebagai pemegang hak cipta utama atas karyanya tersebut.

Mengutip hasil penelitian orang lain, guna memperkuat argumen kita dalam melakukan penelitian bukan tindakan melanggar hak cipta sejauh pengutipan tersebut sesuai aturan dan kaidah keilmuan. Aturan pengutipan atau penulisan sumber utama, sangat banyak style seperti APA, Turabian, Havard dan sebagainya. Untuk setiap institusi memiliki style yang berbeda-beda dengan gaya selingkungnya masing-masing.

Menurut UU Hak Cipta nomor 28 tahun 2014 pasal 44 ayat 1 Penggunaan, pengambilan, Penggandaan, dan/atau pengubahan suatu Ciptaan dan/atau produk Hak Terkait secara seluruh atau sebagian yang substansial tidak dianggap sebagai pelanggaran Hak Cipta jika sumbernya disebutkan atau dicantumkan secara lengkap untuk keperluan a. pendidikan, penelitian, penulisan karya ilmiah, penyusunan laporan, penulisan kritik atau tinjauan suatu masalah dengan tidak merugikan kepentingan yang wajar dari Pencipta atau Pemegang Hak Cipta.

Berdasarkan UU diatas maka pencantuman nama peneliti merupakan suatu keharusan dalam setiap tulisan yang kita kutib, baik dalam isi laporan penelitian maupun didalam daftar bibliografi. Hal ini erat kaitannya sebagai bentuk pengakuan, penghormatan dan penghargaan peneliti akan karya sebelumnya yang telah dibuat. Dan dapat sebagai upaya bahwa karya yang sedang kita buat bukalah plagiat dari karya peneliti sebelumnya. Menurut Soelistyo (2011:91), kedua sikap tersebut sebagai ujud aktualisasi dari hak moral pencipta, yaitu paternity right yang dalam UU Hak 
Cipta nomor 28 tahun 2014 pasal 5 ayat 1 yaitu merupakan hak yang melekat secara abadi pada diri pencipta.

Dalam kaitannya dengan UU Hak Cipta, ada batasan prinsip yang disebut fair use atau fair dealing, yang pada hakekatnya kewajiban untuk menyebutkan sumber bila seseorang mengutip karya cipta orang lain. Sejauh ketentuan tersebut dipenuhi maka tindakan pengutipan tersebut dinilai fair dan tidak dianggap sebagai pelanggaran hak cipta (Soelistyo, 2017). Satu-satunya peran untuk hak cipta dalam domain ini, adalah memberi penulis kontrol atas integritas pekerjaan mereka dan hak untuk diakui dan dikutip dengan tepat.

Pemahaman akan hak cipta sangat perlu diperhatikan dan diajarkan oleh seluruh civitas akademik, karena relevansinya terhadap pemanfaatan sumber-sumber open akses yang disediakan oleh institusi. Salah satu sumber ilmiah open akses yang disediakan oleh institusi adalah repositori institusi.

Repositori merupakan tempat semua karya ilmiah yang dihasilkan oleh institusi. Repositori bersifat elektronik, open akses dan fulltext, sehingga content-nya mudah dimanfaatkan oleh siapa saja baik didalam maupun luar civitas akademik. Bagi institusi, repositori memberikan nilai sangat positif salah satunya adalah untuk menyediakan akses terbuka terhadap karya intelektual institusi kepada khalayak umum (Pandapotan dalam Wiyarsih 2015) atau dikenal sebagai knowledge sharing (Gibbons, 2009; Fuad Gani, 2015). Knowledge sharing akan menciptakan komunikasi ilmiah diantara peneliti, yang diharapkan dapat meningkatkan kualitas hasil dari penelitian yang akan dihasilkannya.

Pengembangan repositori sangat ditentukan oleh kerjasama diantara pustakawan, fakultas dan jurusan. Adanya kerjasama diantara mereka akan meningkatkan pemberdayaan pengembangan repositori menjadi lebih baik. 


\section{Peran pustakawan}

Pustakawan memiliki peran yang strategis dalam administrasi dan mempromosikan keberhasilan membangun repositori institusi (Phillips, Carr, dan Teal, 2005). Kaitannya dalam administrasi, pustakawan harus menyediakan akses terbuka untuk informasi, tetapi di sisi lain pustakawan wajib melindungi karya ilmiah yang terkandung didalamnya (Nilsson, 2016), yang erat kaitannya dengan hak cipta. Sedangkan kaitannya dengan promosi, repositrori sebagai wadah preservasi seluruh dokumen ilmiah milik instritusi.

Repositori institusi menghimpun semua karya ilmiah yang dibuat atau diterbitkan oleh institusi. Repositori bersifat open access sehingga bisa dimanfaatkan seluas-luasnya oleh para mahasiswa, peneliti maupun masyarakat diluar civitas akademik. Pustakawan sebagai pengelola sumber informasi harus memiliki integritas yang tinggi dalam menjalankan profesinya tersebut, salah satunya dengan tidak membatasi siapapun yang ingin mengakses repositori.

Untuk mengemban peran tersebut, pustakawan tidak bisa bekerja sendiri. Kemitraan dengan fakultas menjadi point yang sangat penting dalam bagaimana memanfaatkan open akses dengan tidak melanggar hak cipta.

Pemahaman dan pengetahuan akan hak cipta penting untuk diajarkan kepada mahasiswa. Pustakawan harus memiliki kompetensi akan pemahaman tentang hak cipta yang berkaitan dengan perpustakaan. Beda antara pustakawan dengan praktisi hukum berkenaan dengan hak cipta, tetapi kerjasama antar keduanya menjadi lebih sempurna. Domain utama pustakawan tentang hak cipta lebih pada pengetahuan secara umum yang berkaitan dengan bagaimana memanfaatkan sumber informasi (paraphrase, kutipan langsung dan daftar pustaka) sesuai kaidah keilmuan tanpa melanggar hak cipta penulis yang disebut sebagai copyright advisors (Nilsson 2016). 
Tidak sedikit mahasiswa, dosen bahkan peneliti datang ke pustakawan sekedar untuk meminta saran berkaitan dengan akses dan memanfaatkan informasi yang benar dan tepat supaya tidak dianggap sebagai pelanggaran hak cipta atau plagiarisme. Tetapi terkadang pustakawan kurang percaya diri dengan peran barunya tersebut, meskipun pustakawan memiliki pengetahuan tentang hak cipta.

Kompetensi pustakawan dalam literasi informasi wajib dimiliki karena sangat berperan penting. Pengetahuan tentang hak cipta bisa diberikan kepada mahasiswa, bersamaan dengan rangkaian kegiatan literasi informasi. Kegiatan literasi informasi diberikan kepada mahasiswa terutama mahasiswa baru, yang diharapkan agar mereka selama menuntut ilmu di universitas bisa mengakses dan memanfaatkan sumber informasi yang disediakan oleh perpustakaan secara benar sesuai kaidah keilmuan dan tidak melakukan pelanggaran hak cipta.

Ketrampilan literasi informasi merupakan salah satu solusi untuk mencegah adanya pelanggaran hak cipta. Karena didalam ketrampilan tersebut, mahasiswa diajarkan bagaimana menggunakan informasi secara etis dan legal sesuai kaidah keilmiahan seperti yang termaktub dalam Australian and New Zealand Information Literacy Framework (Bundy, 2004).

\section{Simpulan}

1. Repositori merupakan media preservasi dan sumber informasi dokumen dan karya ilmiah yang diterbitkan oleh institusi.

2. Pustakawan berperan strategis didalam mengembangkan dan mempromosikan repositori institusi.

3. Kemitraan antara pustakawan dengan jurusan dan fakultas sangat menentukan keberhasilan repositori. 


\section{DAFTAR PUSTAKA}

BOAI. 2012. "Ten years from the Budapest open access initiative: setting the default to open." http:// www.budapestopenaccessinitiative.org/boai-10 recommendations.

Bundy, Alan. 2004. "Australian and New Zealand Information Literacy Framework. Principles, standars and practice," 48. doi:10.1057/palgrave.jibs. 8400132 .

Covey, Denise Troll. 2010. "The Ethics of Open Access and Copyright Infringement The Ethics of Open Access and Copyright Infringement." 3rd International Conference on Digital Libraries at Research Showcase@Carnegie Mellon University, no. February. http://repository.cmu.edu/cgi/ viewcontent.cgi? article $=1074 \&$ context=lib_science.

Fuad Gani. 2015. “Tata kelola repository institusi: berbagi informasi dan pengetahuan dengan adil dan beradab."

Gibbons, Susan. 2009. "Benefits of an institutional repository." Library Technology Reports 40 (4): 11-16. doi:http://dx.doi. org/10.5860/ltr.40n4.

Henry Soelistyo. 2011. Plagiarisme: pelanggaran hak cipta dan etika. Jakarta: PT. Kanisius.

Irawan, Prasetya. 2000. Logika dan prosedur penelitian. Jakarta: STIA-LAN Press.

Nilsson, Inga-lill. 2016. "Developing new copyright services in academic libraries." Insights the UKSG journal 29 (1): 78-83. doi:10.1629/uksg.276.

Phillips, Holly, Richard Carr, dan Janis Teal. 2005. "Leading roles for reference librarians in institutional repositories: One library's experience." Reference Services Review 33 (3): 30111. doi:10.1108/00907320510611339.

Ratanya, Felicitas Ciabere. 2017. "Institutional repository: access and use by academic staff at Egerton University, Kenya." 
Library Management 38 (4-5): 276-84. doi:10.1108/LM-022017-0018.

Wiyarsih. 2015. "Pemanfaatan Koleksi Repository Perpustakaan Fakultas MIPA UGM Menggunakan Eprints." Ilmu Perpustakaan dan Informasi 11 (2). https://jurnal.ugm.ac.id/ bip/article/view/10035/7546.

\section{Wawancara}

Soelistyo, Henry (Dosen, Praktisi hak cipta). Wawancara oleh P. Iman Hery Wahyudi. Universitas Pelita Harapan. Tanggal 18 dan 20 April 2017 
